\title{
Apoptosis-inducing protein, AIP, from parasite-infected fish induces apoptosis in mammalian cells by two different molecular mechanisms
}

\author{
M Murakawa ${ }^{1}$, S-K Jung ${ }^{1,2}, \mathrm{~K} \mathrm{lijima}^{3}$ and S Yonehara ${ }^{\star, 1}$ \\ 1 Institute for Virus Research, Kyoto University, Shogoin, Sakyo-ku, Kyoto 606- \\ 8507, Japan \\ ${ }^{2}$ M, F, L Science Center, Tensei-suisan Co., 1-25 Nakase-dori, Karatsu, Saga \\ 847-0193, Japan \\ ${ }^{3}$ Nippi Research Institute of Biomatrix, 1-1-1 Senju-midoricho, Adachi-ku \\ Tokyo 120-8601, Japan \\ * Corresponding author: S Yonehara, Institute for Virus Research, Kyoto \\ University, Shogoin, Sakyo-ku, Kyoto 606-8507, Japan. Tel: 81-75-751-4783 \\ Fax: 81-75-751-4784; E-mail: syonehar@virus.kyoto-u.ac.jp
}

Received 29.5.00; revised 10.9.00; accepted 8.11.00 Edited by $D$ Green

\begin{abstract}
AIP (apoptosis-inducing protein) is a protein purified and cloned from Chub mackerel infected with the larval nematode, Anisakis simplex, which induces apoptosis in various mammalian cells including human tumor cell lines. AIP has shown structural and functional homology to Lamino acid oxidase (LAO) which oxidizes several L-amino acids including L-lysine and AIP-induced apoptosis has been suggested to be mediated by $\mathrm{H}_{2} \mathrm{O}_{2}$ generated by $L A O$ activity of AIP. In this study, we confirmed that recombinant AIP generated enough $\mathrm{H}_{2} \mathrm{O}_{2}$ in culture medium to induce rapid apoptosis in cells and this apoptosis was clearly inhibited by co-cultivation with antioxidants such as catalase and $\mathrm{N}$ acetyl-cysteine. Surprisingly, however, we found that AIP still could induce $\mathrm{H}_{2} \mathrm{O}_{2}$-independent apoptosis more slowly than $\mathrm{H}_{2} \mathrm{O}_{2}$-dependent one in $\mathrm{HL}-60$ cells even in the presence of antioxidants. In addition, the HL-60-derived cell line $\mathrm{HP100-1}$, which is a $\mathrm{H}_{2} \mathrm{O}_{2}$-resistant variant, underwent apoptosis on treatment with AIP with a similar delayed time course. The latter apoptosis was completely blocked by addition of L-lysine to the culture medium, which is the best substrate of AIP as LAO, indicating that decreased concentration of L-lysine in the culture medium by AIPtreatment induced apoptosis. We also showed that the both apoptosis by AIP were associated with the release of cytochrome $c$ from mitochondria and activation of caspase9, and overexpressed Bcl-2 could inhibit both of the AIPinduced apoptosis. These results indicate that AIP induces apoptosis in cells by two distinct mechanisms; one rapid and mediated by $\mathrm{H}_{2} \mathrm{O}_{2}$, the other delayed and mediated by deprivation of L-lysine, both of which utilize caspase-9/ cytochrome c system. Cell Death and Differentiation (2001) 8 , 298-307.
\end{abstract}

Keywords: AIP; L-amino acid oxidase; $\mathrm{H}_{2} \mathrm{O}_{2}$; L-amino acid depletion

Abbreviations: AIP, Apoptosis-inducing protein; FITC, fluorescein isothiocyanate; LAO, L-amino acid oxidase; $\mathrm{mAb}$, monoclonal antibody; NAC, N-acetyl-cysteine; OPD, o-Phenylendiamine; PI, propidium iodide; SDS - PAGE, sodium dodecyl sulfate polyacrylamide gel electrophoresis; ZVAD-fmk, Benzyloxycarbonyl-ValAla-Asp- $\mathrm{CH}_{2} \mathrm{OC}(\mathrm{O})$-2,6-dichlorobenzene

\section{Introduction}

Apoptosis is a physiological death essential to the normal development and homeostatic maintenance of multicellular organisms. $^{1,2}$ Apoptosis refers to the morphological changes exhibited by actively dying cells that include cell shrinkage, membrane blebbing, and chromatin condensation. Many kinds of stimuli have been reported to induce apoptosis in a variety of mammalian cell systems. These include ligation of Fas, tumor necrosis factor receptors and other death receptors by their ligand or agonistic antibodies, ${ }^{3-7}$ deprivation of growth factors, and cytotoxic stimuli such as ionizing radiation, UV irradiation, and anticancer drugs. ${ }^{1,2}$ Recently, in addition to these well characterized stimuli, some L-amino acid oxidase enzymes (LAO) from snake venom were reported to induce apoptosis in mammalian cell lines, such as Apoxin I from rattlesnake venom. ${ }^{8-11}$ LAO might play a role in cell death caused by snake venom.

LAO (EC 1.4.3.2) is a dimeric flavoprotein which catalyzes the stereospecific deamination of an L-amino acid substrate to an $\alpha$-keto acid along with the production of $\mathrm{NH}_{3}$ and $\mathrm{H}_{2} \mathrm{O}_{2}$. We recently cloned a novel apoptosisinducing protein (AIP) from Anisakis-infected mackerels which is homologous in structure to $\mathrm{LAO},{ }^{12}$ and this protein is also capable of generating $\mathrm{H}_{2} \mathrm{O}_{2}$ in vitro by catalyzing the oxidation of some L-amino acids, especially L-lysine, indicating that AIP belongs to LAO family. Because AIP was specifically purified from fluid in capsules where parasites were confined in vermiculose mackerels, AIP was speculated to be involved in defense against parasites, but its actual role is still unclear. Since elucidation of the molecular mechanism of AIP-induced apoptosis might lead to better understanding of the physiological role of AIP, we investigated the molecular basis for apoptosis by AIP. In this study we demonstrate that AIP-induced apoptosis is mediated not only by $\mathrm{H}_{2} \mathrm{O}_{2}$ but also by rapid depletion of $\mathrm{L}$ lysine, which is an essential amino acid, suggesting that depletion of lysine by AIP may play an important role in host defense by inhibiting maturation and/or growth of parasites. 


\section{Results \\ Expression and purification of recombinant AIP protein}

To study the molecular mechanism of AIP-induced apoptosis, we prepared purified recombinant AIP protein using a baculovirus expression system. Expression of AIP protein in insect cells infected with baculovirus encoding AIP cDNA was ascertained by Western blotting with anti-AIP mAb (Figure 1A). Recombinant AIP expressed in insect cells was purified by sequential column chromatography and the purity was confirmed by sodium dodecyl sulfate-polyacrylamide gel electrophoresis (SDS-PAGE) (Figure 1B). The apoptosisinducing activity of the purified recombinant AIP was compared with that of native AIP purified from mackerels infected with Anisakis. ${ }^{12}$ Figure 1C clearly shows the recombinant AIP to possess the same specific activity as that of native AIP.

\section{AlP-induced fast apoptosis is mediated by $\mathrm{H}_{2} \mathrm{O}_{2}$}

In amino acid sequence, AIP showed significant homology to L-amino acid oxidase (LAO), suggesting that AIP itself has LAO activity. In fact, AIP showed LAO activity, producing $\mathrm{H}_{2} \mathrm{O}_{2}$ by oxidizing several L-amino acids including L-lysine. ${ }^{12}$ To elucidate whether the apoptosis-inducing activity of AIP is associated with LAO activity, we quantified AIP-induced $\mathrm{H}_{2} \mathrm{O}_{2}$ in RPMI 1640 medium. When the medium was incubated with AIP at $100 \mathrm{ng} / \mathrm{ml}$, more than $80 \mu \mathrm{M} \mathrm{H}_{2} \mathrm{O}_{2}$ was produced within $2 \mathrm{~h}$ (Figure 2A), which is enough to induce apoptosis in HL-60 cells (data not shown). To establish whether AIP induced apoptosis is mediated by $\mathrm{H}_{2} \mathrm{O}_{2}$, the effects of antioxidants, catalase and N-acetyl-cysteine (NAC) were studied in AIPtreated cells. After $6 \mathrm{~h}$ incubation with AIP, apoptotic cells with subdiploid DNA were quantified by flow cytometer and agarose gel electrophoresis, and it was found that the antioxidants completely inhibited apoptosis induced by AIP (Figure 2B,C). These results show that AIP-induced fast apoptosis is mediated by $\mathrm{H}_{2} \mathrm{O}_{2}$.

\footnotetext{
AIP can also induce cell death independent of $\mathrm{H}_{2} \mathrm{O}_{2}$ Interestingly, however, we found that AIP could induce apoptosis in HL-60 cells after incubation for $24 \mathrm{~h}$ in the presence of catalase. As shown in Figure $3 A, B$, AIP at $100 \mathrm{ng} / \mathrm{ml}$ could not induce apoptosis in HL-60 cells within $8 \mathrm{~h}$ in the presence of catalase, but cell death came to be observed after $10 \mathrm{~h}$ incubation. The same result was obtained in the presence of NAC instead of catalase (data not shown), suggesting that this delayed cell death is not mediated by $\mathrm{H}_{2} \mathrm{O}_{2}$. This delayed cell death was accompanied by DNA fragmentation (Figure 3B), morphological changes such as membrane blebbing (Figure $3 \mathrm{C}$ ), and chromatin condensation (Figure 3D), which are typical characteristics of apoptosis. In addition, the late cell death was blocked by a caspase inhibitor, z-VAD-fmk (Figure 3B), which is well known to inhibit apoptosis. Moreover, AIP could also induce apoptosis in the $\mathrm{H}_{2} \mathrm{O}_{2}$-resistant cell line HP100-1 derived from HL-60 cells. Apoptosis was observed in HP100-1 cells after $24 \mathrm{~h}$ incubation with $100 \mathrm{ng} / \mathrm{ml}$ of AIP, although cell
}

A
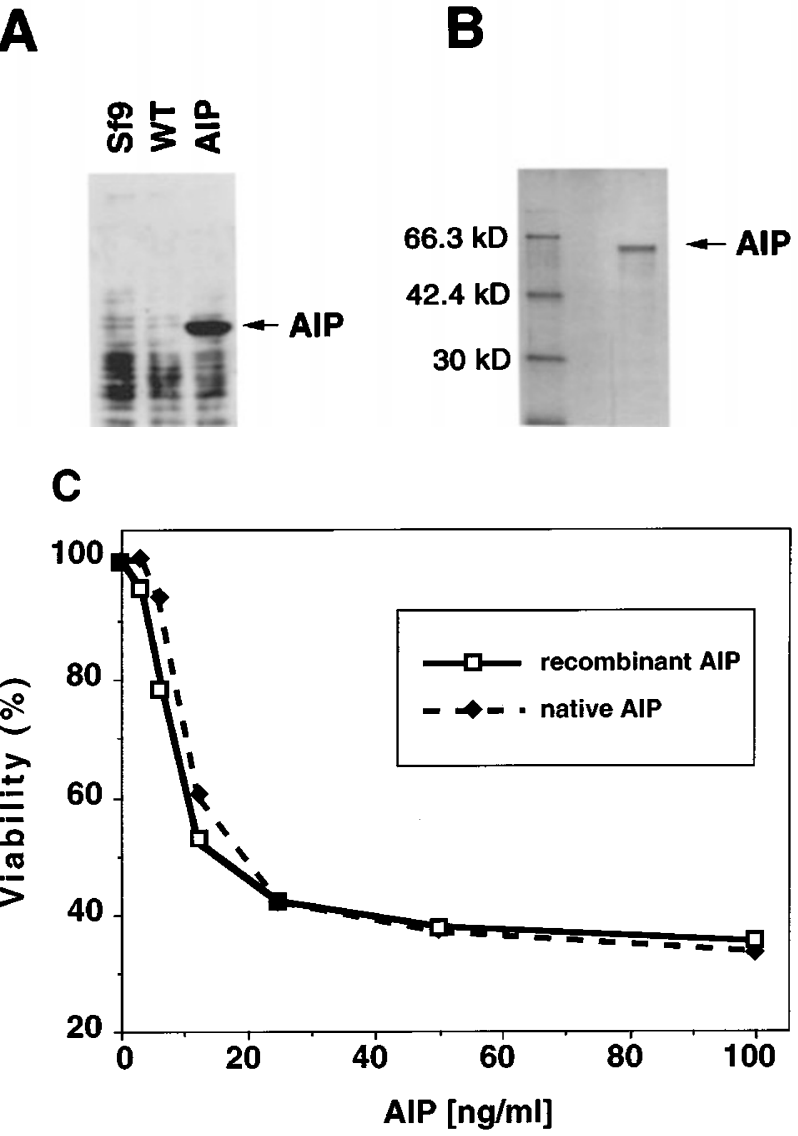

Figure 1 Purification of recombinant AIP from Sf9 infected with baculovirus harboring AIP CDNA. Recombinant AIP was generated in a baculovirus expression system, and then purified by sequential column chromatography. (A) Western blot analysis was performed with anti-AIP mAb and lysate of Sf9 cells (Sf9), Sf9 cells infected with wild type baculovirus (WT) and Sf9 cells infected with baculovirus harboring AIP cDNa (AIP). (B) The purified recombinant AIP was analyzed by SDS-PAGE and detected by silver staining. (C) Cell-killing activity of purified AIP from mackerels (native AIP) and Sf9 cells (recombinant AIP) was analyzed by MTS assay (Promega)

death was never observed in HP100-1 cells after $24 \mathrm{~h}$ incubation with $1 \mathrm{mM} \mathrm{H}_{2} \mathrm{O}_{2}$ (Figure 4A: right panel). All the results show that AIP induces apoptosis in cells by two distinct mechanisms with different time courses; one fast and dependent on $\mathrm{H}_{2} \mathrm{O}_{2}$, the other slow and independent of $\mathrm{H}_{2} \mathrm{O}_{2}$.

\section{AIP-induced delayed apoptosis is mediated by depletion of L-lysine}

Since AIP produces $\mathrm{H}_{2} \mathrm{O}_{2}$ by disrupting L-lysine as a main substrate, ${ }^{12}$ which is an essential amino acid, we postulated that the delayed apoptosis induced by AIP is caused by rapid depletion of L-lysine from the medium. Then, we analyzed the effect of an excess of L-lysine on AIP-induced delayed apoptosis. When excess amounts of L-lysine $(1 \mathrm{mg} / \mathrm{ml})$ and antioxidants (catalase or NAC) were added to the culture medium before incubation with AIP, both the fast and the delayed apoptosis were clearly suppressed in HL-60 cells (Figure 4: left and middle panel). In addition, AIP-induced 


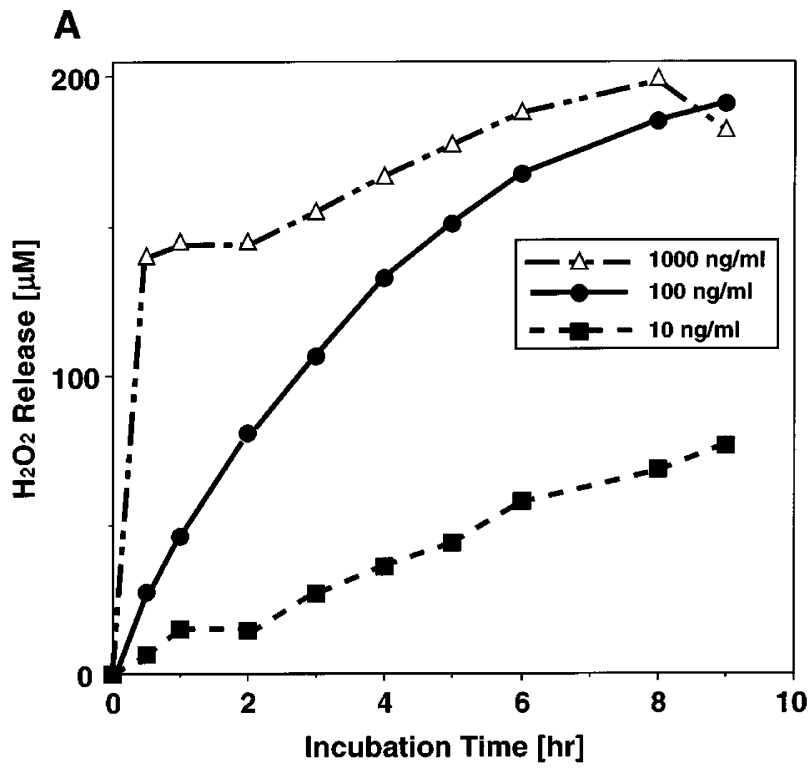

B



C
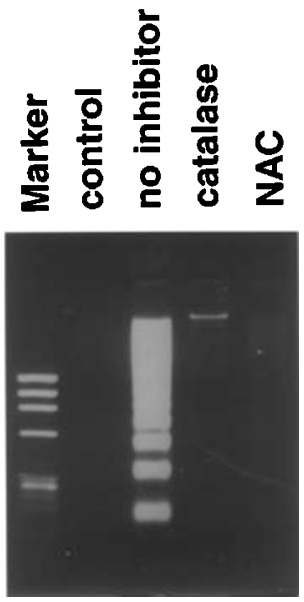

Figure 2 Analysis of AIP-induced rapid apoptosis. (A) Generation of $\mathrm{H}_{2} \mathrm{O}_{2}$ by incubation of AIP in RPMI 1640 medium: Recombinant AIP was incubated with RPMI 1640 containing peroxidase and OPD for the periods indicated as described in Materials and Methods. (B,C) Rapid apoptosis induced by AIP is mediated by $\mathrm{H}_{2} \mathrm{O}_{2}$ generated in RPMI 1640 medium. HL-60 cells were pretreated with or without 5000 units/ml of catalase, $10 \mathrm{mM} \mathrm{NAC}$, or $200 \mu \mathrm{M} \mathrm{ZVAD-fmk} \mathrm{for} 1 \mathrm{~h}$ and then cultured with or without (control) $100 \mathrm{ng} / \mathrm{ml}$ AIP for $6 \mathrm{~h}$. The percentages of apoptotic cells induced by AIP were quantified by measuring subdiploid cells by FACScan flow cytometer (B) and DNA fragmentation was analyzed as described in Materials and Methods (C)

apoptosis in HP100-1 was also completely blocked by adding excess amounts of L-lysine (Figure 4: right panel).

To confirm that AIP-induced delayed apoptosis is mediated by rapid depletion of L-lysine from the culture medium, we designed the following experiment. RPMI 1640 medium containing $10 \%$ FBS (RPMI+FBS) was preincubated with $100 \mathrm{ng} / \mathrm{ml}$ AIP and catalase for $24 \mathrm{~h}$ and subsequently, the LAO activity of AIP was inactivated by heating for $30 \mathrm{~min}$ at $80^{\circ} \mathrm{C}$. Then, this conditioned medium containing neither $\mathrm{H}_{2} \mathrm{O}_{2}$ nor active AIP was analyzed for activity to induce apoptosis in HL-60 cells. Figure 5A,B shows that HL-60 cells died by apoptosis after cultivation with the conditioned medium for $24 \mathrm{~h}$ at $37^{\circ} \mathrm{C}$. Interestingly, the apoptosis was completely inhibited by adding $40 \mu \mathrm{g} / \mathrm{ml}$ L-lysine to the conditioned medium, while other essential amino acids could not suppress the apoptosis. Control RPMI+FBS medium with AIP, which had been heatinactivated without pre-incubation, did not show any apoptosis-inducing activity, indicating that the cell death was not induced by the remaining LAO activity of the heat- 

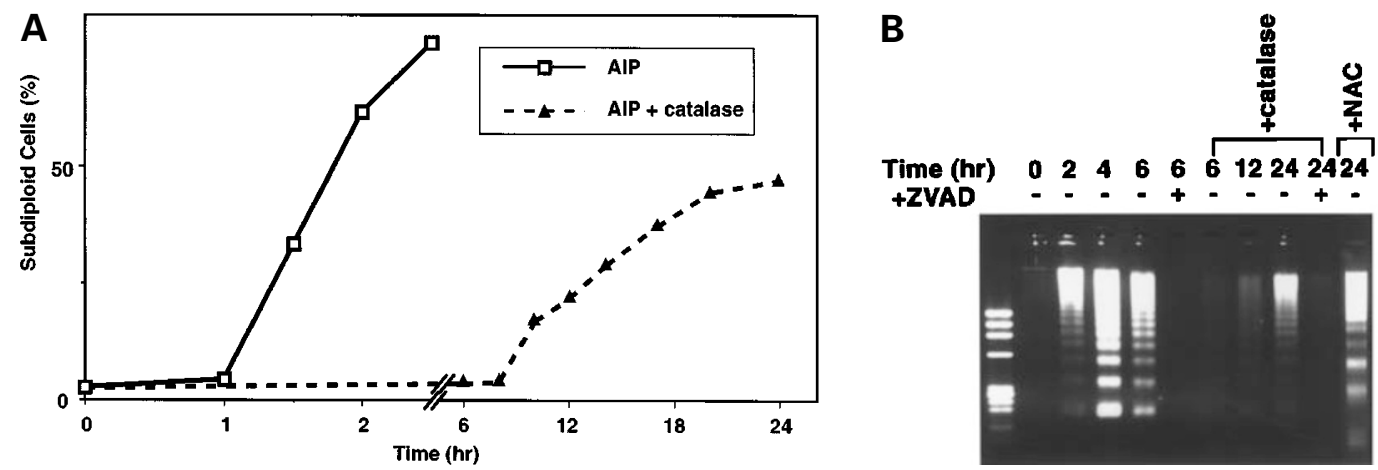

C Phase-contrast

$6 \mathrm{~h}$

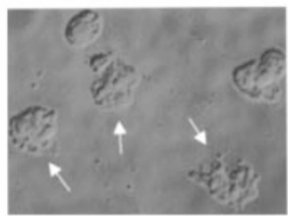

+ catalase $6 h$

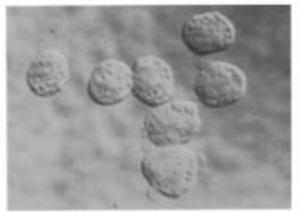

D Hoechst

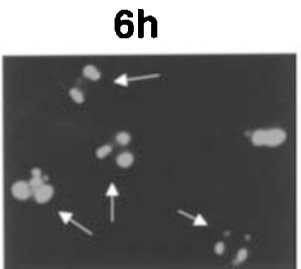

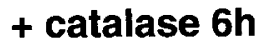

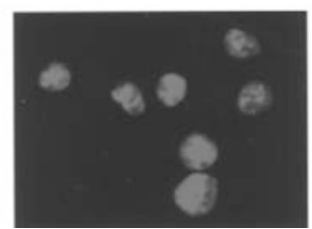

+ catalase 24h

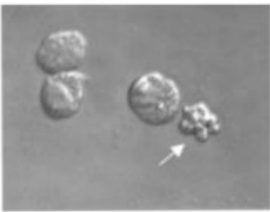

\section{+ catalase 24h}

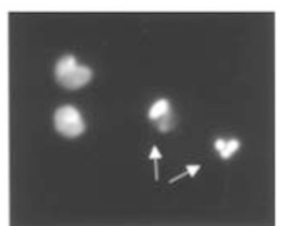

Figure 3 Analysis of AIP-induced delayed apoptosis. HL-60 cells were precultured at $37^{\circ} \mathrm{C}$ in the presence or absence of 5000 units $/ \mathrm{ml} \mathrm{catalase,} 10 \mathrm{mM} \mathrm{NAC}$ or $200 \mu \mathrm{M}$ Z-VAD-fmk and then cultured with $100 \mathrm{ng} / \mathrm{ml}$ AIP for the indicated times. The percentages of apoptotic cells were quantified by measuring subdiploid cells by FACScan flow cytometer (A). DNA fragmentation was analyzed by agarose gel electrophoresis (B). AIP-treated HL-60 cells in the presence or absence of catalase were observed under a phase contrast microscope (C). The nuclei were stained with Hoechst 33528 and the stained nuclei were photographed (D)

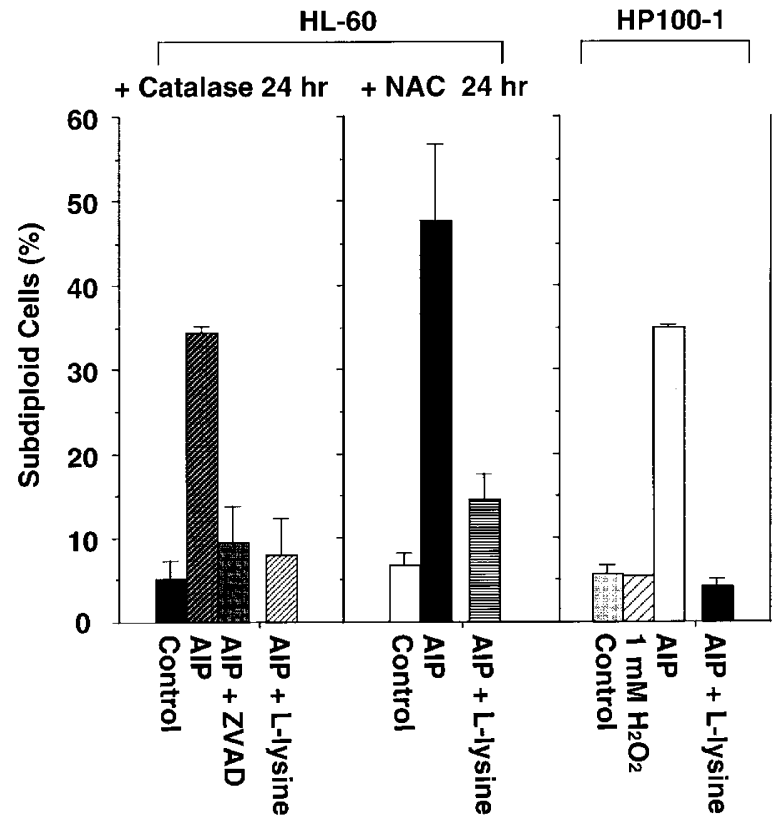

Figure 4 Additional L-lysine can inhibit AIP-induced slow apoptosis. HL-60 cells were pretreated with catalase (left panel) or NAC (middle panel) for $1 \mathrm{~h}$ and then cultured with $100 \mathrm{ng} / \mathrm{ml}$ AIP for $24 \mathrm{~h}$ in the presence or absence of $200 \mu \mathrm{M}$ Z-VAD-fmk or $1 \mathrm{mg} / \mathrm{ml}$ L-lysine. The percentages of subdiploid cells were quantified by FACScan flow cytometer. HP100-1, a $\mathrm{H}_{2} \mathrm{O}_{2}$-resistant cell line derived from $\mathrm{HL}-60$, was cultured with $1 \mathrm{mM} \mathrm{H}_{2} \mathrm{O}_{2}$ or $100 \mathrm{ng} / \mathrm{ml}$ AIP for $24 \mathrm{~h}$ in the presence or absence of $1 \mathrm{mg} / \mathrm{ml} \mathrm{L}$-lysine and then analyzed by FACScan flow cytometer (right panel). The data represent means \pm S.D. (bars) of three independent experiments 
inactivated AIP. In addition, cells were shown to grow normally in RPMI+FBS pre-heated at $80^{\circ} \mathrm{C}$, indicating that heated culture medium at this temperature did not influence cell growth significantly.

To directly show the depletion of L-lysine from culture medium by AIP, we analyzed amino acid levels in culture medium after treatment with or without AIP for $24 \mathrm{~h}$ in the presence of catalase. As shown in Figure 5C,D, L-lysine was specifically depleted in AIP-treated culture medium, while the levels of other amino acids were not changed significantly. Then, we examined whether the synthetic culture medium without L-lysine could induce apoptosis by using RPMI 1640 SELECT-AMINE Kit (Life Technologies, Gaitherburg, MD, USA). Figure 5E shows that DNA fragmentation associated with apoptosis was observed in HL-60 cells after $24 \mathrm{~h}$ cultivation at $37^{\circ} \mathrm{C}$ with synthetic RPMI 1640 without L-lysine containing 10\% FBS dialyzed against PBS. All the results show that the delayed apoptosis induced by AIP is caused by depletion of Llysine from culture medium.
A

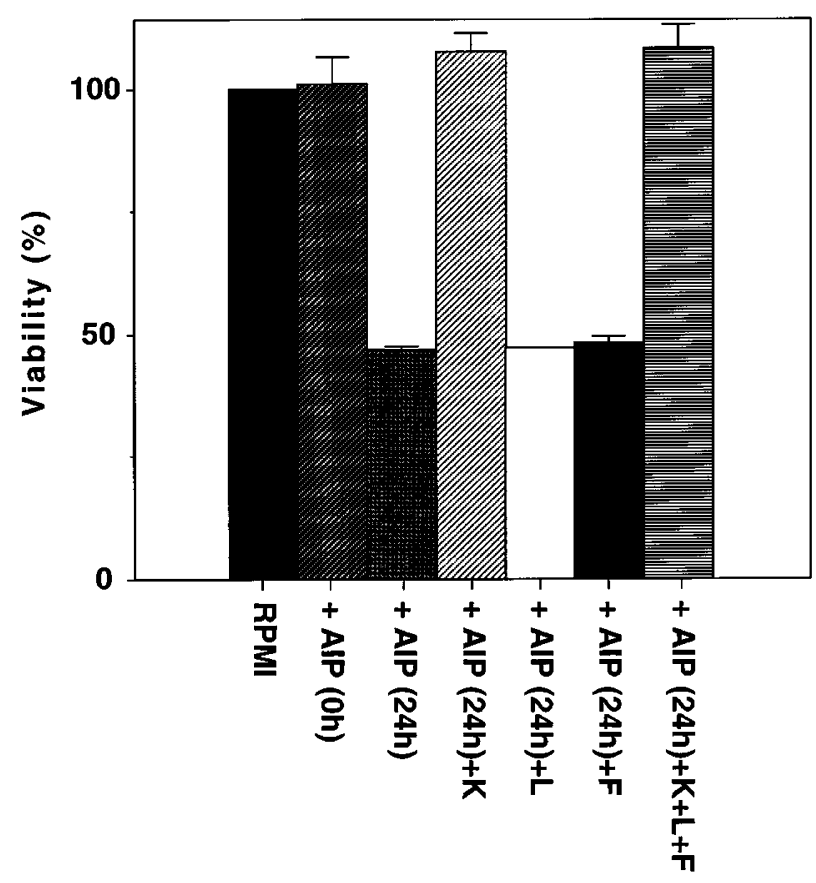

B

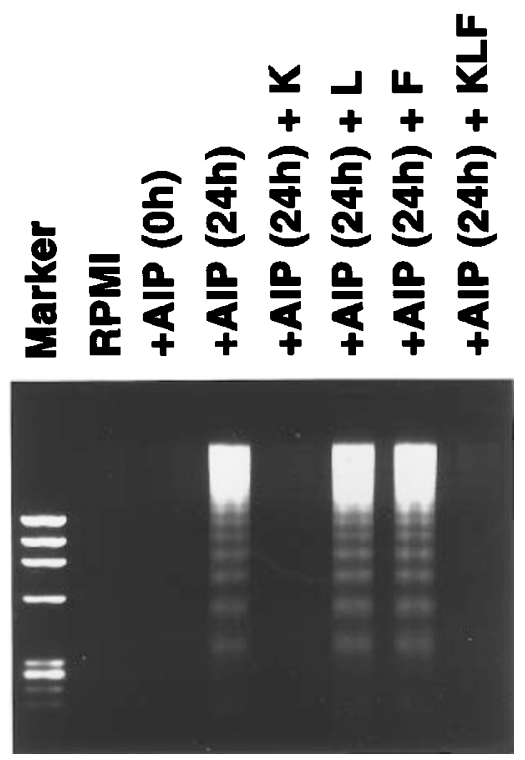

C

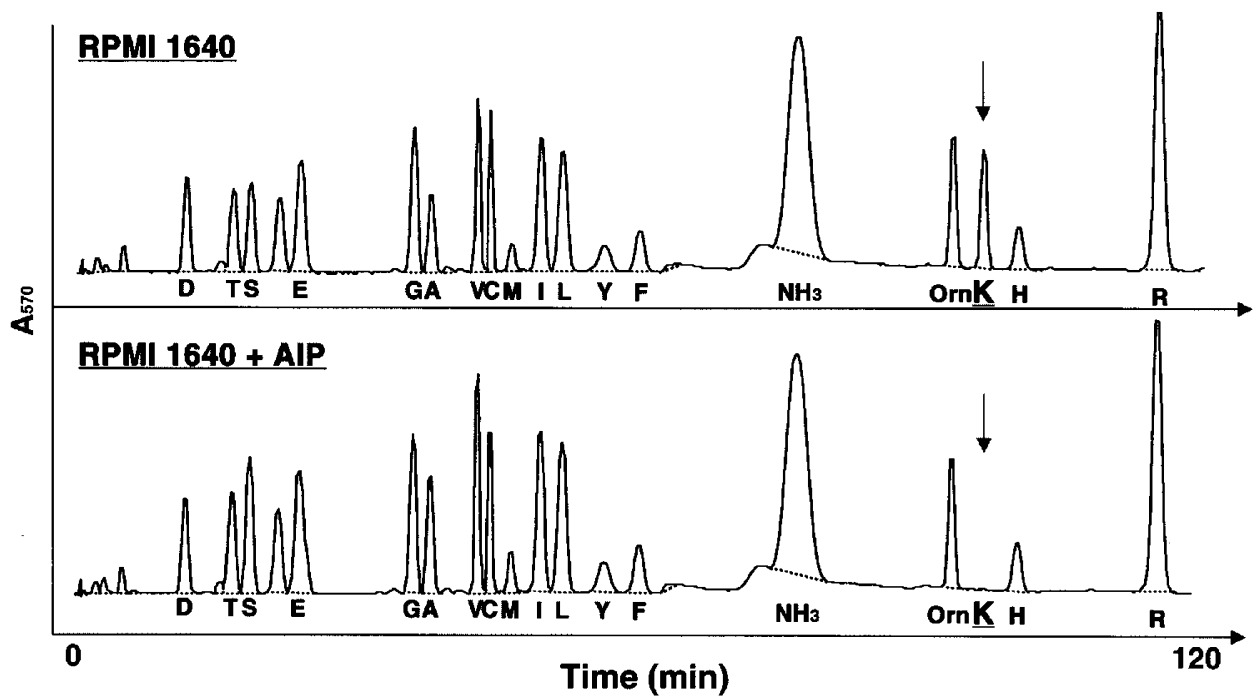




\section{Both the fast and the delayed apoptosis are associated with release of cytochrome $c$ from mitochondria and activation of caspase-9/-3}

We further examined the molecular mechanisms of both fast and delayed apoptosis induced by AIP. In both cases, the apoptosis was clearly accompanied by the activation of caspase-3 (Figure 6A). These results together with the finding that the caspase inhibitor Z-VAD-fmk suppresses both pathways of apoptosis (Figures $2 \mathrm{~B}$ and 4 ) clearly indicate that AIP-induced fast and delayed apoptosis is mediated by activated caspases.

Then, we examined what type of signals to be utilized in the activation of caspase- 3 in fast and delayed apoptosis. Figure $6 \mathrm{~B}$ shows that the release of cytochrome $c$ from mitochondria to cytosol accompanied both the fast and the delayed apoptosis induced by AIP and was not inhibited by ZVAD-fmk, indicating that the release was induced upstream of the activation of caspases. Since cytochrome $c$ release has been reported necessary for the activation of caspase- 9 with the help of Apaf- $1,{ }^{13}$ we analyzed the activation of caspase- 9 by Western blotting. Caspase- 9 was activated in both pathways of AIP-induced apoptosis (Figure 6C). We also examined whether caspase-8, which is another initiator caspase, was activated in AIP-induced apoptosis. As shown in Figure 6C, the active p18 fragment of caspase-8 was not observed in AIP-induced apoptosis, although partial proces- sing of the caspase-8 was observed in AIP-induced $\mathrm{H}_{2} \mathrm{O}_{2}$ dependent apoptosis. In contrast with AIP-induced apoptosis, we could detect the active p18 fragment clearly in caspase-8dependent Fas-induced apoptosis (data not shown). These results suggest that AIP can induce apoptosis in various cells by two different molecular mechanisms, both of which, however, utilize the Apaf-1/caspase-9/cytochrome $c$ system to activate the caspase cascade.

\section{Both the fast and the delayed apoptosis are blocked by Bcl-2}

To support the idea that both of the fast and delayed apoptosis by AIP utilize mitochondria-dependent pathway, we analyzed whether Bcl-2 could inhibit AIP-induced apoptosis using a human lymphoma cell line, HPB-ALL and its Bcl-2-overexpressing cell line, HPB-ALL/Bcl-2. We confirmed that HPB$\mathrm{ALL} / \mathrm{Bcl}-2$ cells strongly express $\mathrm{Bcl}-2$ protein by Western blotting (Figure 7A). Apoptosis was detected in AIP-treated cells by staining with Annexin V-FITC and PI (Figure 7B). Annexin $\mathrm{V}$ was shown to recognize the exposed phosphatidylserine at the surface of the apoptotic cells, and PI does not stain early apoptotic cells, but stains late apoptotic and necrotic cells. After $6 \mathrm{~h}$ incubation with $200 \mathrm{ng} / \mathrm{ml}$ AIP, $27.8 \%$ of the population were detected as Annexin V-FITC-positive and PI-negative cells (early apoptotic cells). After $48 \mathrm{~h}$ incubation with $200 \mathrm{ng} / \mathrm{ml}$ AIP in the presence of 5000 units/
D

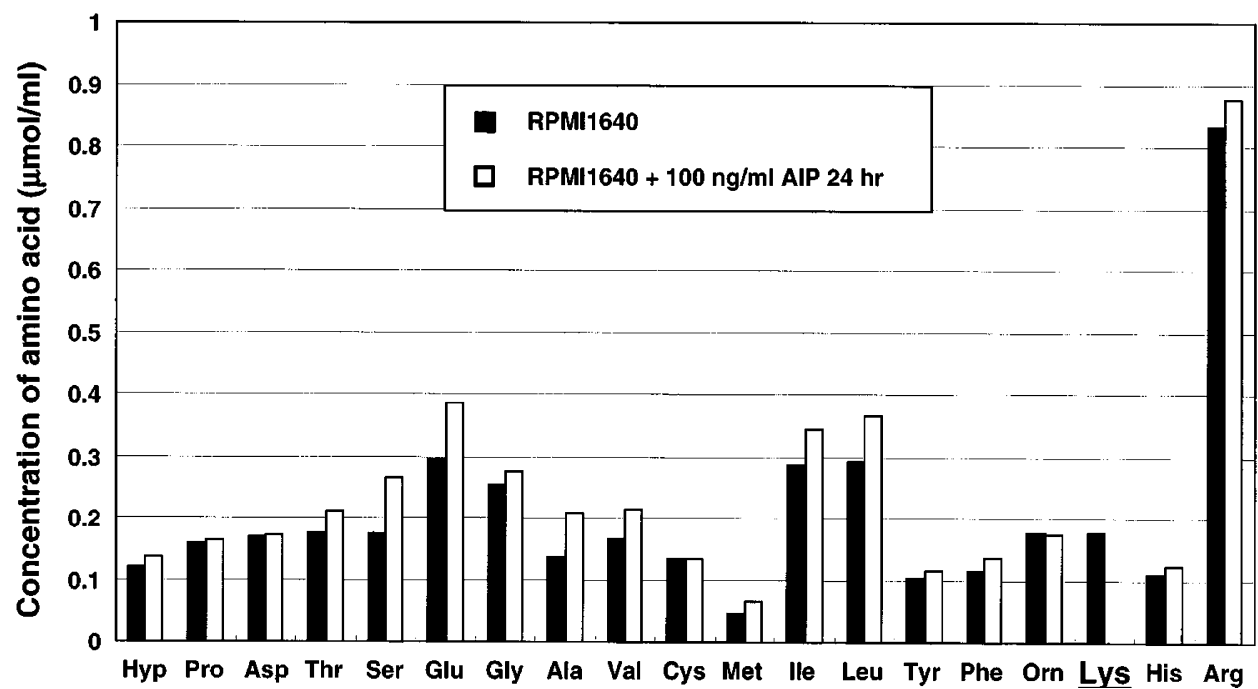

E

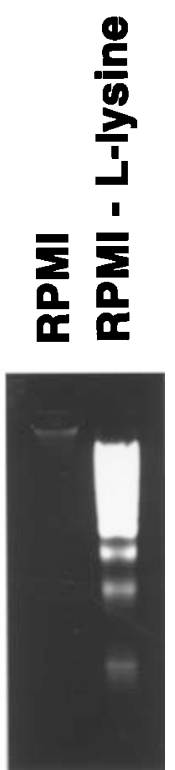

Figure 5 Apoptosis-inducing activity of AIP-treated conditional medium. Conditioned medium was prepared as follows. AIP at $100 \mathrm{ng} / \mathrm{ml}$ was added to RPMI 1640 containing $10 \% \mathrm{FBS}$, and the medium was heated for $30 \mathrm{~min}$ at $80^{\circ} \mathrm{C}$ to inactivate AIP before [AIP $\left.(0 \mathrm{~h})\right]$ or after [AIP $\left.(24 \mathrm{~h})\right]$ pre-incubation for $24 \mathrm{~h}$ at $37^{\circ} \mathrm{C}$. After two washes with PBS, HL-60 cells were cultured with the AIP-treated and heat-inactivated conditioned medium for $24 \mathrm{~h}$ with or without additional essential amino acids, that is, $40 \mu \mathrm{g} / \mathrm{ml}$ L-lysine $(\mathrm{K}), 50 \mu \mathrm{g} / \mathrm{ml} \mathrm{L-leucine}(\mathrm{L}), 15 \mu \mathrm{g} / \mathrm{ml} \mathrm{L}$-phenylalanine $(\mathrm{F})$, or combinations of them $(\mathrm{K}+\mathrm{L}+\mathrm{F})$. (A) Cell viability was analyzed by MTS assay (Promega) (B) DNA was extracted from the cells and analysed by $2 \%$ agarose gel electrophoresis. (C,D) RPMI 1640 medium containing $10 \%$ FBS for cultivation of $\mathrm{HL}-60$ cells was incubated with or without $100 \mathrm{ng} / \mathrm{ml}$ of AIP for $24 \mathrm{~h}$ in the presence of catalase and then the remaining amino acid level of the medium was monitored as described in Materials and Methods (C). Standard one letter symbols for amino acids are shown, and 'orn' indicates ornithine. Concentration of amino acids in the culture medium incubated with or without $100 \mathrm{ng} / \mathrm{ml}$ AIP for $24 \mathrm{~h}$ were quantified as described in Materials and Methods (D). 'Hyp' indicates hydroxyproline. (E) HL-60 cells were washed with PBS and then cultured at $37^{\circ} \mathrm{C}$ for $24 \mathrm{~h}$ with synthetic RPMI 1640 without L-lysine containing $10 \%$ FBS dialyzed against PBS. After $24 \mathrm{~h}$ cultivation, DNA was extracted from the cells and fragmented DNA was detected by agarose gel electrophoresis 
A

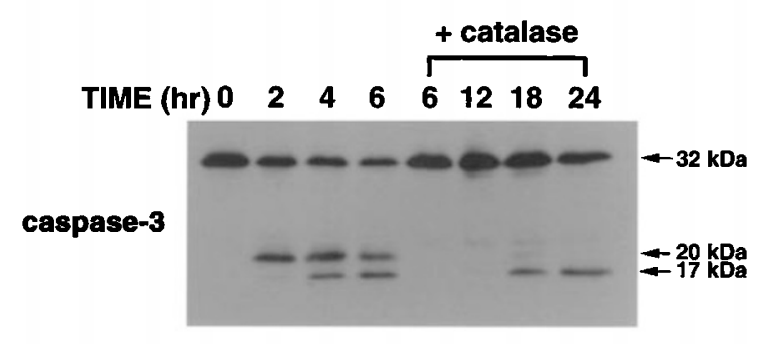

B
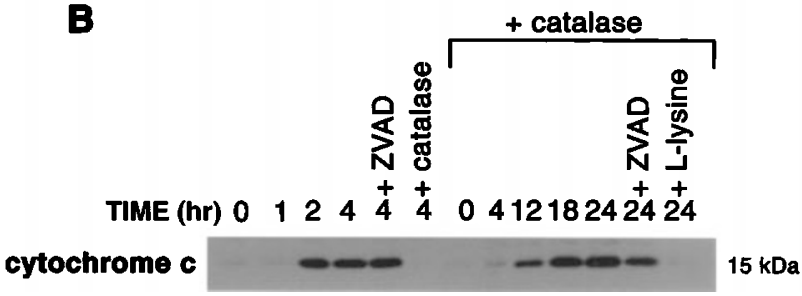

C
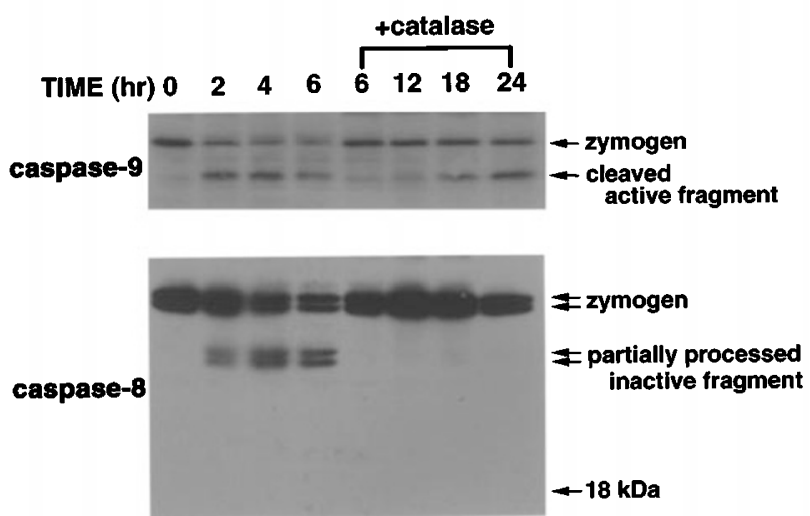

Figure 6 Immunoblot analysis of AIP-induced caspase-3/-8/-9 cleavage and cytochrome $c$ release from mitochondria. HL-60 cells were incubated with or without $200 \mu \mathrm{M}$ Z-VAD-fmk or $1 \mathrm{mg} / \mathrm{ml} \mathrm{L-lysine} \mathrm{and} \mathrm{then} \mathrm{treated} \mathrm{with} 100 \mathrm{ng} / \mathrm{ml}$ AIP in the presence or absence of 5000 units/ml catalase for the periods indicated. Cell lysates (30 $\mu \mathrm{g} / \mathrm{lane}$ ) were separated by $15 \%$ PAGE and subjected to immunoblot analysis with anti-caspase-3 antibody (A). Soluble cytosolic fractions (10 $\mu \mathrm{g} / \mathrm{lane}$ ) were electrophoresed and subjected to immunoblot analysis with anti-cytochrome c mAb (B). Cell lysates ( $30 \mu \mathrm{g} / \mathrm{lane})$ were separated by $12 \%$ PAGE and subjected to immunoblot analysis with anti-caspase-8 or anti-caspase-9 antibody (C)

$\mathrm{ml}$ catalase, $11.0 \%$ of the population were Annexin V-FITCpositive and PI-negative. In contrast, both of $\mathrm{H}_{2} \mathrm{O}_{2}$-dependent and -independent apoptosis by AIP could not be detected by Annexin V-FITC staining in HPB-ALL/Bcl-2 cells (Figure 7B). Essentially the same results were obtained by analyses of DNA fragmentation and nuclear fragmentation detected by Hoechst staining (data not shown). These data strongly suggest that both of AIP induced fast and delayed apoptosis are mediated by Bcl-2-inhibitable mitochondria-dependent pathway.

\section{Discussion}

Recently, we purified and cloned a novel apoptosis-inducing protein (AIP) from Chub mackerel infected with the larval nematode, Anisakis simplex. ${ }^{12}$ The amino acid sequence of AIP deduced from the cloned cDNA suggested that AIP is a member of L-amino acid oxidase (LAO). And AIP was shown to have LAO activity catalyzing the oxidation of L-lysine. In this report, we reconfirmed that the apoptosis-inducing activity of AIP with a rapid time course is mediated by $\mathrm{H}_{2} \mathrm{O}_{2}$ generated by catalyzing oxidation of L-amino acids in culture medium. However, we also found that AIP showed an apoptosisinducing activity with a delayed time course when $\mathrm{H}_{2} \mathrm{O}_{2}$ was disrupted by catalase. This $\mathrm{H}_{2} \mathrm{O}_{2}$-independent delayed apoptosis-inducing activity was indicated to be mediated by depletion of L-lysine from culture medium. Thus, AIP can induce apoptosis in various cells by two different molecular mechanisms.

Previously, Suhr et al. showed that LAO purified from Korean snake venom induced apoptosis in mammalian cells and suggested the LAO-induced apoptotic mechanism to be distinguished from the $\mathrm{H}_{2} \mathrm{O}_{2}$-induced one. ${ }^{9}$ We presume that the apoptosis they observed might be also caused by depletion of L-amino acids from the culture medium. 
A

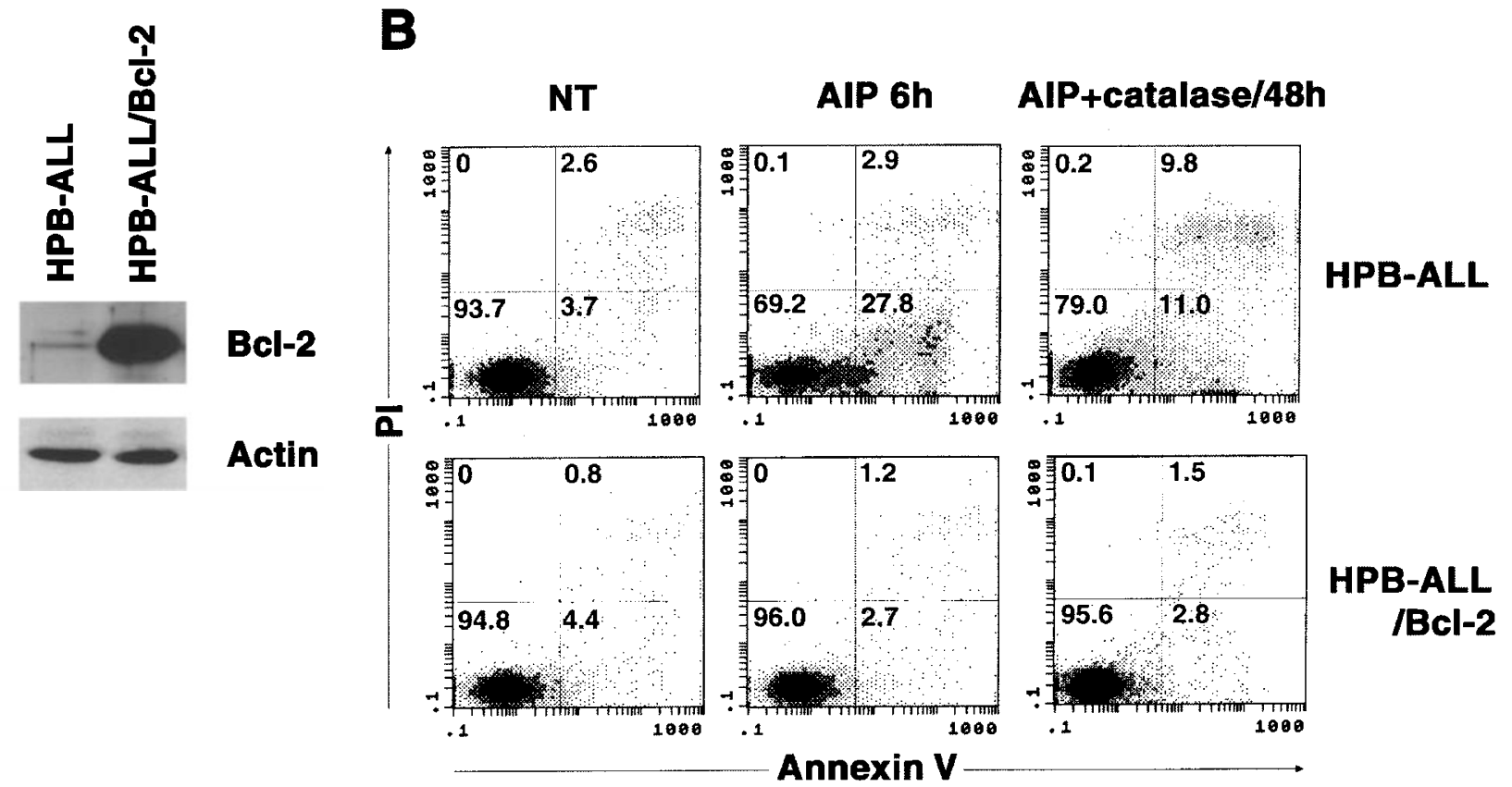

Figure $7 \mathrm{Bcl}-2$ can inhibit AIP-induced apoptosis. (A) Equal amounts of cell lysates (50 $\mu \mathrm{g} / \mathrm{lane})$ from HPB-ALL and HPB-ALL/Bcl-2 cells were separated by SDS-PAGE and subjected to immunoblot analysis with anti-Bcl-2 antibody. (B) HPB-ALL and HPB-ALL/Bcl-2 cells were treated with $200 \mathrm{ng} / \mathrm{ml}$ AIP for $6 \mathrm{~h}$ (AIP $6 \mathrm{~h}$ ), or for $48 \mathrm{~h}$ in the presence of 5000 units/ml catalase (AIP $48 \mathrm{~h}$ ), and then apoptotic cells were measured by Annevin V-binding and PI-staining using MEBCYTO-Apoptosis Kit (Medical \& Biological Laboratories). NT; not treated with AIP. The proportion (\%) of respective fraction is shown in the figure

In this study, we indicated that depletion of L-lysine from culture medium can cause apoptosis in HL-60 cells. Several previous studies showed that depletion of a specific amino acid induces cell death. L-asparaginase which resolves L-asparagine was reported to be effective in eliminating some lymphoma cells as an anticancer reagent, ${ }^{14-16}$ suggesting that depletion of L-asparagine induces the death of some lymphoma cells. In addition, indoleamine 2,3-dioxigenase (IDO) which resolves Ltryptophane was recently indicated to play an important role in prevention of allogenic fetal rejection through elimination of maternal immunocytes specific for an allotype of fetus. ${ }^{17}$ We suspect that L-asparaginase and IDO induce apoptosis in lymphoma cells and immunocytes, respectively. Actually, IFN- $\gamma$-induced induction of IDO was reported to cause apoptosis in IDO-expressing cells. ${ }^{18}$ Thus, apoptosis-induction by depletion of a specific amino acid has physiological roles such as elimination of cancer cells and prevention of allogenic fetal rejection. AIP might also play a physiological role in the prevention of mackerels from becoming infected with parasites such as Anisakis. In fact, significant amounts of AIP were found in the inner cavity of capsules surrounding Anisakis, where Anisakis stays at larva III stage without maturing to imagines (S-K Jung and S Yonehara, unpublished observations). AIP may suppress the maturation of Anisakis in the capsules although no such inhibition has been shown to be directly induced by AIP.

We analyzed the target cell specificity of AIP, and found that AIP induces apoptosis in a wide variety of cultured human and murine cells including lymphoid cells, fibro- blasts and epithelial cells (M Murakawa, S-K Jung and S Yonehara, unpublished observations). The two different apoptosis-inducing mechanisms of AIP may confer the broad target cell specificity. Some lymphoma cells were reported to produce antioxidant molecules. For example, human $\mathrm{T}$ cell leukemia virus I-infected cells and human acute lymphoblastic leukemia cell line CEM were reported to secrete thioredoxin and catalase, respectively. ${ }^{19-21}$ AIP might still be able to induce apoptosis in these cells producing various antioxidant molecules through the $\mathrm{H}_{2} \mathrm{O}_{2}$ independent mechanism. AIP actually induced apoptosis in HP100-1 cells overexpressing catalase, ${ }^{22}$ which are resistant to $\mathrm{H}_{2} \mathrm{O}_{2}$-induced cell death (Figure 4), and some ATL-derived cell lines (data not shown). Thus, AIP or AIP homologues may be clinically useful to induce apoptosis in cancer cells even if the cancer cells show antioxidant activity.

Here we show that both of apoptosis-inducing activities of AIP were mediated by the release of cytochrome $c$ from mitochondria upstream of the activation of caspases. The released cytochrome $c$ activates caspase- 9 with the help of Apaf-1, and activated caspase- 9 induces the activation of caspase-3 and other downstream caspases. ${ }^{13,23}$ The activated caspases were reported to directly induce apoptosis by cleaving many so-called death substrates ${ }^{24}$ such as PARP, ${ }^{25}$ MST $^{26,27}$ and ICAD/DFF $-45 .^{28-30}$ AIP induces two different apoptosis-inducing signals, generation of $\mathrm{H}_{2} \mathrm{O}_{2}$ and depletion of L-lysine, and these signals were shown to converge in the release of cytochrome $c$ from mitochondria. It remains to be resolved how these two different signals induce the release of cytochrome $c$. 


\section{Materials and Methods}

\section{Reagent}

Anti-AIP mAb was prepared as described. ${ }^{12}$ Anti-cytochrome $c$ mAb, anti-Bcl-2 antibody and anti-caspase-3 antibody were purchased from PharMingen (San Diego, CA, USA). Anti-caspase-8 mAb and antiCaspase-9 antibody were purchased from Medical \& Biological Laboratories (Nagoya, Japan) and New England Biolabs (Beverly, MA, USA), respectively. Benzyloxycarbonyl-Val-Ala-Asp- $\mathrm{CH}_{2} \mathrm{OC}(\mathrm{O})$ 2,6-dichlorobenzene (Z-VAD-fmk) was purchased from Peptide Institute (Osaka, Japan) and dissolved in dimethyl sulfoxide (DMSO) at $20 \mathrm{mM}$. Catalase, $\mathrm{N}$-acetyl-cysteine (NAC) and all other chemicals employed in this study were purchased from Wako Pure Chemicals (Tokyo, Japan), Nacalai tesque (Kyoto, Japan), or Sigma (St. Louis, MO, USA).

\section{Cell lines and cell culture}

Human promyelocytic leukemia cell line $\mathrm{HL}-60, \mathrm{HL}-60$-derived $\mathrm{H}_{2} \mathrm{O}_{2}$ resistant cell line HP100-1 ${ }^{22}$ and human lymphoma cell line HPB-ALL were maintained in RPMI 1640 medium (Nissui, Tokyo, Japan) supplemented with $10 \%(\mathrm{v} / \mathrm{v})$ fetal bovine serum, $20 \mathrm{mM}$ HEPES $(\mathrm{pH}$ 7.4), $50 \mu \mathrm{M} \beta$-mercaptoethanol, 50 units $/ \mathrm{ml}$ penicillin, and $50 \mu \mathrm{g} / \mathrm{ml}$ streptomycin. The Sf9 insect cells (Invitrogen, Carlsbad, CA, USA) were maintained in IPL-41 medium (Life Technologies, Gaithersburg, MD, USA) supplemented with $10 \%(\mathrm{v} / \mathrm{v})$ heat-inactivated fetal bovine serum.

\section{Expression and purification of recombinant AIP}

Recombinant AIP was prepared with the Bac-to-Bac Baculovirus Expression System (Life Technologies, Gaitherburg, MD, USA) as follows. Recombinant baculovirus harboring AIP was generated by transfection of Sf 9 cells with recombinant bacmid generated by cloning the entire coding sequence of AIP cDNA into pFastBacl vector. Sf9 cells were infected with the baculovirus and cultured for $84 \mathrm{~h}$. After one wash with cold PBS, cells were frozen in liquid nitrogen. Cell pellets were thawed on ice and suspended in $30 \mathrm{ml}$ of $250 \mathrm{mM} \mathrm{Tris-} \mathrm{HCl}(\mathrm{pH}$ 8.0) containing $1 \mathrm{mM} \mathrm{PMSF}$, and cells were disrupted by four cycles of freezing in liquid nitrogen and thawing at $37^{\circ} \mathrm{C}$. After centrifugation for 10 min at 10000 r.p.m. at $4^{\circ} \mathrm{C}$, the supernatant was applied to a Con A-Sepharose column (12 ml, Pharmacia Biotech, Uppsala, Sweden). Fractions containing apoptosis-inducing activity were eluted with $72 \mathrm{ml}$ of PBS containing $0.5 \mathrm{M}$ Metyl $\alpha$-D-Mannopyranoside and concentrated with an Ultrafree-15 centrifugal filter (Millipore Corp., Bedford, MA, USA). The concentrated material was loaded on a Hiload 16/60 Superdex 200 column (Pharmacia Biotech) in 20 mM Bis-Tris$\mathrm{HCl}(\mathrm{pH} 6.5)$ containing $5 \mathrm{mM} \mathrm{NaCl}$ and eluted with the same buffer. Fractions containing apoptosis-inducing activity were collected, concentrated, and subsequently loaded on a Mono $Q$ column (Pharmacia Biotech). The column was eluted with a $18 \mathrm{ml}$ gradient of $5 \mathrm{mM}-1 \mathrm{M} \mathrm{NaCl}$, and the fractions containing apoptosis-inducing activity were concentrated and then loaded again on a Hiload 16/60 Superdex 200 column in PBS. The fractions containing AIP were collected and the purity was confirmed by SDS-PAGE and staining the gel with a two-dimensional silver stain kit (Daiichi, Tokyo, Japan).

\section{$\mathrm{H}_{2} \mathrm{O}_{2}$ release assay}

RPMI 1640 medium (100 $\mu$ /sample) was incubated with AIP at various concentrations, 20 units $/ \mathrm{ml}$ peroxidase and $500 \mu \mathrm{g} / \mathrm{ml} o$-Phenylendiamine (OPD) at $37^{\circ} \mathrm{C}$. Then, the quantity of the generated $\mathrm{H}_{2} \mathrm{O}_{2}$ was determined by measuring absorbance at a wavelength of $450 \mathrm{~nm}$ under a spectrophotometer.

\section{Quantification of subdiploid cells}

HL-60 cells were pretreated with or without $200 \mu \mathrm{M}$ Z-VAD-fmk, $1 \mathrm{mg} /$ $\mathrm{ml}$ L-lysine, or antioxidants ( 5000 units $/ \mathrm{ml}$ catalase or $10 \mathrm{mM} \mathrm{NAC}$ ) for $1 \mathrm{~h}$, and then cells were treated with $100 \mathrm{ng} / \mathrm{ml}$ AIP for 6 or $24 \mathrm{~h}$. Cells were harvested, fixed in $70 \%$ ethanol, treated with RNase A $(100 \mu \mathrm{g} /$ $\mathrm{ml})$ in PBS, and stained with propidium iodide solution $(50 \mu \mathrm{g} / \mathrm{ml}$ in PBS). Cells were analyzed using a FACScan flow cytometer (Becton Dickinson, Braintree, MA, USA).

\section{DNA fragmentation assay}

Cells $\left(5 \times 10^{5}\right)$ were suspended in $100 \mu$ of $10 \mathrm{mM}$ Tris- $\mathrm{HCl}(\mathrm{pH} 7.5)$ containing $10 \mathrm{mM}$ EDTA, 0.5\% Triton X-100 and $200 \mu \mathrm{g} / \mathrm{ml}$ RNase A and incubated for $10 \mathrm{~min}$ at room temperature. After centrifugation at 15000 r.p.m. for $20 \mathrm{~min}$ at $4^{\circ} \mathrm{C}$, the supernatant was incubated for $1 \mathrm{~h}$ at $37^{\circ} \mathrm{C}$. Then, $1 \mu \mathrm{l}$ of $20 \mathrm{mg} / \mathrm{ml}$ Proteinase $\mathrm{K}$ was added, and the solution was incubated for an additional hour. DNA was precipitated with $50 \%$ isopropanol containing $420 \mathrm{mM} \mathrm{NaCl}$, dissolved in $\mathrm{TE}$ solution, separated in $2 \%$ agarose gels, and stained with ethidium bromide. The stained gels were photographed on a UV transilluminator.

\section{MTS assay}

The viability of HL-60 cells $\left(5 \times 10^{4}\right.$ cells/well in 96 -well plates) treated with AIP was measured with a CellTiter $96{ }^{\mathbb{R}}$ AQueous Assay Kit (Promega, Madison, WI, USA) according to the manufacturer's instructions.

\section{Annexin V-FITC/PI labeling assay}

HPB-ALL cells were treated with $200 \mathrm{ng} / \mathrm{ml} \mathrm{AIP} \mathrm{for} 6$ or $48 \mathrm{~h}$ in the presence of catalase. Apoptotic cells accompanied with the exposure of phosphatidylserine at the cell surface without breakdown of cell membrane were stained by Annexin V-FITC and PI using MEBCYTOApoptosis Kit (Medical \& Biological Laboratories, Nagoya, Japan) according to manufacturer's instructions and analyzed by EPICS flow cytometer (Beckman Coulter, Inc., Fullerton, CA, USA).

\section{Quantification of amino acid composition}

HL-60 cells were cultured in phenol red-free RPMI 1640 medium containing $10 \%$ FBS with or without $100 \mathrm{ng} / \mathrm{ml}$ AIP in the presence of catalase for $24 \mathrm{~h}$. After removing the cells, the medium was filtered off by UFV5 BCC filter (Millipore Corp., Bedford, MA, USA) to remove protein, and $10 \mu \mathrm{l}$ of the filtrate was loaded onto a column packed with Ion Exchange Resin equipped on an L-8500 amino acid analyzer (Hitachi Instruments Service Co., Tokyo, Japan) using citrate buffers and lithium chroride gradient. Amino acids in the eluate were monitored by post-column reaction with ninhydrin.

\section{Western blot analysis}

For quantification of cytochrome $c$ outside of mitochondria, a soluble cytosolic fraction was prepared essentially as described. ${ }^{31}$ In brief, cells were washed once with ice-cold PBS, and then the cell pellet was suspended in five volumes of ice-cold buffer $(20 \mathrm{mM}$ Hepes- $\mathrm{KOH} \mathrm{pH}$ 7.4, $10 \mathrm{mM} \mathrm{KCl}, 1.5 \mathrm{mM} \mathrm{MgCl} 2,1 \mathrm{mM}$ EDTA, $1 \mathrm{mM}$ EGTA, $1 \mathrm{mM}$ DTT, $1 \mathrm{mM}$ PMSF, $3.8 \mu \mathrm{g} / \mathrm{ml}$ aprotinin). After sitting on ice for $15 \mathrm{~min}$, 
cells were disrupted using a Dounce homogenizer with a loose-fitting pestle. After five strokes, the cell suspension was centrifuged at $10000 \times \mathrm{g}$ for $10 \mathrm{~min}$ at $4^{\circ} \mathrm{C}$ and the supernatant was further centrifuged at $100000 \times g$ for $1 \mathrm{~h}$. The resulting supernatant was used as the soluble cytosolic fraction. For immunoblotting of Actin, Bcl2 and caspase-3/-8/-9, cells were washed once with ice-cold PBS, and resuspended in lysis buffer $(20 \mathrm{mM}$ Hepes- $\mathrm{KOH} \mathrm{pH} 7.4,150 \mathrm{mM}$ $\mathrm{NaCl}, 1 \mathrm{mM}$ EDTA, $1 \%$ Triton X-100, $1 \mathrm{mM}$ PMSF, $3.8 \mu \mathrm{g} / \mathrm{ml}$ aprotinin). After sitting on ice for $20 \mathrm{~min}$, the cytosolic fraction was obtained by centrifugation at 15000 r.p.m. for $20 \mathrm{~min}$, subjected to electrophoresis on a 12 or $15 \%$ SDS-polyacrylamide gel, and then electrophoretically transferred to a polyvinyliden difluoride membrane (Millipore Corp.). The membrane was blocked with TBST (20 mM Tris$\mathrm{HCl} \mathrm{pH} \mathrm{7.5,150} \mathrm{mM} \mathrm{NaCl,} \mathrm{0.1 \%} \mathrm{Tween} \mathrm{20)} \mathrm{containing} \mathrm{5 \%} \mathrm{skim} \mathrm{milk}$ for $1 \mathrm{~h}$ at room temperature, and each antibody was applied in the same blocking solution. After $1 \mathrm{~h}$ incubation at room temperature, membranes were washed with TBST and incubated for $1 \mathrm{~h}$ with horseradish peroxidase-conjugated anti-rabbit (for Actin, Bcl-2 and caspase-3/-9) or anti-mouse (for caspase-8) IgG (Amersham Pharmacia Biotech, Little Chalfont, UK). The specific signals were detected on X-ray films using Renaissance chemiluminescence reagent (NEM Life Science Products, Boston, MA, USA).

\section{Acknowledgements}

We thank Drs. Hirotaka Kazama and Kosei Ito for technical advice about flow cytometric analysis. We also thank Drs. Kazuhiro Sakamaki and Shuji Kishi for careful reading of the manuscript and HPB-ALL/Bcl-2, respectively. This work was supported in part by Grants-in-Aid from the Ministry of Education, Science, Sports and Culture of Japan, and performed in part through Special Coordination Funds of the Science and Technology of the Japanese Government.

\section{References}

1. Evan G and Littlewood T (1998) A matter of life and cell death. Science 281: $1317-1322$

2. Green DRand Reed JC (1998) Mitochondria and apoptosis. Science 281:13091312

3. Yonehara S, Ishii A and Yonehara M (1989) A cell-killing monoclonal antibody (anti-Fas) to a cell surface antigen co-downregulated with the receptor of tumor necrosis factor. J. Exp. Med. 169: 1747-1756

4. Trauth BC, Klas C, Peters AM, Matzku S, Moller P, Falk W, Debatin KM and Krammer PH (1989) Monoclonal antibody-mediated tumor regression by induction of apoptosis. Science 245: 301-305

5. Itoh N, Yonehara S, Ishii A, Yonehara M, Mizushima S, Sameshima M, Hase A, Seto Yand Nagata S (1991) The polypeptide encoded by the cDNA for human cell surface antigen Fas can mediate apoptosis. Cell 66: 233-243

6. Nagata S (1997) Apoptosis by death factor. Cell $88: 355-365$

7. Ashkenazi A and Dixit VM (1998) Death receptors: signaling and modulation. Science 281: 1305-1308

8. Torii S, Naito M and Tsuruo T (1997) Apoxin I, a novel apoptosis-inducing factor with L-amino acid oxidase activity purified from Western diamondback rattlesnake venom. J. Biol. Chem. 272: 9539-9542

9. Suhr SM and Kim DS (1996) Identification of the snake venom substance that induces apoptosis. Biochem. Biophys. Res. Commun. 224: 134-139

10. Raibekas AA and Massey V (1998) Primary structure of the snake venom Lamino acid oxidase shows high homology with the mouse B cell interleukin 4induced Fig1 protein. Biochem. Biophys. Res. Commun. 248: 476-478
11. Souza DH, Eugenio LM, Fletcher JE, Jiang MS, GarrattRC, Oliva G and Selistrede-Araujo HS (1999) Isolation and structural characterization of a cytotoxic Lamino acid oxidase from agkistrodon contortrix laticinctus snake venom: preliminary crystallographic data. Arch. Biochem. Biophys. 368: 285-290

12. Jung SK, Mai A, Iwamoto M, Arizono N, Fujimoto D, Sakamaki Kand Yonehara S (2000) Purification and cloning of an apoptosis-inducing protein derived from fish infected with Anisakis simplex, a causative nematode of human anisakiasis. J. Immunol. 165: 1491-1497

13. LiP, Nijhawan D, Budihardjo I, Srinivasula SM, Ahmad M, Alnemri ES and Wang X (1997) Cytochrome $c$ and dATP-dependent formation of Apaf-1/caspase-9 complex initiates an apoptotic protease cascade. Cell 91: 479-489

14. Story MD, Voehringer DW, Stephens LC and Meyn RE (1993) L-asparaginase kills lymphoma cells by apoptosis. Cancer Chemother. Pharmacol. 32: 129-133

15. Bussolati O, Belletti S, Uggeri J, Gatti R, Orlandini G, Dall'Asta V and Gazzola GC (1995) Characterization of apoptotic phenomena induced by treatment with $L$ asparaginase in NIH3T3 cells. Exp. Cell Res. 220: 283-291

16. Ueno T, Ohtawa K, Mitsui K, Kodera $Y$, Hiroto M, Matsushima A, Inada $Y$ and Nishimura $H$ (1997) Cell cycle arrest and apoptosis of leukemia cells induced by L-asparaginase. Leukemia 11: 1858-1861

17. Munn DH, Zhou M, Attwood JT, Bondarev I, Conway SJ, Marshall B, Brown C and Mellor AL (1998) Prevention of allogeneic fetal rejection by tryptophan catabolism. Science 281: 1191-1193

18. Konan KV and Taylor MW (1996) Treatment of ME180 cells with interferongamma causes apoptosis as a result of tryptophan starvation. J. Interferon. Cytokine Res. 16: 751-756

19. Wakasugi N, Tagaya Y, Wakasugi H, Mitsui A, Maeda M, Yodoi J and Tursz T (1990) Adult T-cell leukemia-derived factor/thioredoxin, produced by both human T-Iymphotropic virus type I- and Epstein-Barr virus-transformed lymphocytes, acts as an autocrine growth factor and synergizes with interleukin 1 and interleukin 2. Proc. Natl. Acad. Sci. USA 87: 8282-8286

20. Iwata S, Hori T, Sato N, Hirota K, Sasada T, Mitsui A, Hirakawa T and Yodoi $J$ (1997) Adult T cell leukemia (ATL)-derived factor/human thioredoxin prevents apoptosis of lymphoid cells induced by L-cystine and glutathione depletion: possible involvement of thiol-mediated redox regulation in apoptosis caused by pro-oxidant state. J. Immunol. 158: 3108-3117

21. Sandstrom PA and Buttke TM (1993) Autocrine production of extracellular catalase prevents apoptosis of the human CEM T-cell line in serum-free medium. Proc. Natl. Acad. Sci. USA 90: 4708-4712

22. Kasugai I and Yamada M (1989) Adaptation of human leukemia HL-60 cells to hydrogen peroxide as oxidative stress. Leuk. Res. 13: 757-762

23. Zou H, Henzel WJ, Liu X, Lutschg A and Wang X (1997) Apaf-1, a human protein homologous to $\mathrm{C}$. elegans CED-4, participates in cytochrome c-dependent activation of caspase-3. Cell 90: 405-413

24. Earnshaw WC, Martins LM and Kaufmann SH (1999) Mammalian Caspases: Structure, Activation, Substrates, and Functions during Apoptosis. Annu. Rev. Biochem. 68: 383-424

25. D'Amours D, Duriez PJ, Orth K, Shah RG, Dixit VM, Earnshaw WC, Alnemri ES and Poirier GG (1997) Purification of the death substrate poly(ADP-ribose) polymerase. Anal. Biochem. 249: 106-108

26. Graves JD, Gotoh Y, Draves KE, Ambrose D, Han DK, Wright M, Chernoff J, Clark EA and Krebs EG (1998) Caspase-mediated activation and induction of apoptosis by the mammalian Ste2-like kinase Mst1. EMBO J. 17: 2224-2234

27. Lee KK, Murakawa M, Nishida E, Tsubuki S, Kawashima S, Sakamaki K and Yonehara S (1998) Proteolytic activation of MST/Krs, STE20-related protein kinase, by caspase during apoptosis. Oncogene 16: 3029-3037

28. Enari M, Sakahira H, Yokoyama H, Okawa K, Iwamatsu A and Nagata S (1998)A caspase-activated DNase that degrades DNA during apoptosis, and its inhibitor ICAD. Nature 391: 43-50

29. Sakahira H, Enari M and Nagata S (1998) Cleavage of CAD inhibitor in CAD activation and DNA degradation during apoptosis. Nature 391: $96-99$

30. Liu X, Zou H, Slaughter C and Wang X (1997) DFF, a heterodimeric protein that functions downstream of caspase-3 to trigger DNA fragmentation during apoptosis. Cell 89: 175-184

31. Yang J, Liu X, Bhalla K, Kim CN, Ibrado AM, Cai J, Peng TI, Jones DP and Wang X (1997) Prevention of apoptosis by Bcl-2: release of cytochrome C from mitochondria blocked. Science 275: 1129-1132 